\title{
A conceptual framework to evaluate human-wildlife interactions within coupled human and natural systems
}

\author{
$\underline{\text { Anita T. Morzillo }}^{1}, \underline{\text { Kirsten M. de Beurs }}^{2}$ and Chelsea J. Martin-Mikle ${ }^{2}$
}

\begin{abstract}
Landscape characteristics affect human-wildlife interactions. However, there is a need to better understand mechanisms that drive those interactions, particularly feedbacks that exist between wildlife-related impacts, human reaction to and behavior as a result of those impacts, and how land use and landscape characteristics may influence those components within coupled human and natural systems. Current conceptual models of human-wildlife interactions often focus on species population size as the independent variable driving those interactions. Such an approach potentially overlooks important feedbacks among and drivers of human-wildlife interactions that result from mere wildlife presence versus absence. We describe an emerging conceptual framework that focuses on wildlife as a driver of human behavior and allows us to better understand linkages between humans, wildlife, and the broader landscape. We also present results of a pilot analysis related to our own ongoing study of urban rodent control behavior to illustrate one application of this framework within a study of urban landscapes.
\end{abstract}

Key Words: coupled human and natural systems; human-wildlife conflict; human-wildlife interactions; landscape ecology; pesticides; rodenticides; wildlife management

\section{INTRODUCTION}

Urban landscapes are diverse (Theobald 2004), and their dynamic characteristics influence biodiversity and wildlife distributions (Savard et al. 2000, DeStefano and DeGraaf 2003, McKinney 2008). Many studies have evaluated interactions between humans and wildlife in urban areas and potential impacts of residential activities on wildlife (e.g., Lepczyk et al. 2004a, b, Faeth et al. 2005). However, few studies have linked human-wildlife interactions to broader coupled human and natural systems processes across landscapes, consisting of human and natural components and the interactions (or feedbacks) between them (Liu et al. 2007), particularly within urban ecosystems (Morzillo and Schwartz 2011). With ongoing human population shifts from rural to suburban and urban areas (Hobbs and Stoops 2002, McKinney 2002), there is a need to better understand such linkages. Such understanding might not only lead to better management for urban wildlife and natural resources, but also provide insight into how human decision making at multiple spatial scales and among diverse land uses affects and is affected by interactions between humans and wildlife.

\section{BACKGROUND AND CONTEXT}

Human-wildlife interactions occur in many contexts, including recreation (Marzano and Dandy 2012, Hughes 2013), hunting (Morzillo et al. 2009), subsistence (Natcher et al. 2012), transportation (Foster and Humphrey 1995), land use (Groepper et al. 2012), and passive-appreciation activities (Morzillo et al. 2007, Fuller et al. 2008). From a human perspective, such interactions range across a continuum from positive to negative (Riley et al. 2002) and result in a continuous need for assessment to manage for potential human-wildlife conflict.

Research on human-wildlife conflict often investigates ecological or social indicators that predict potential for conflict. In both the ecological and social examples, population size of a species, or a related variable, often is used as an independent variable to assess potential for wildlife-human conflict. Ecologically, biological characteristics of a wildlife population are used as guidance for management decisions (Bolen and Robinson 1999). For example, in one compilation of papers, four major themes, ecology, human dimensions, management, and transportation, focused on population size, particularly perceived overabundance, within the context of deer management in developed landscapes (Nielsen and Porter 2011). More broadly, DeStefano and Deblinger (2005) described three driving forces of suburban wildlife management: wildlife abundance or density, type of human-wildlife interaction, and personal experience. In that study, both biophysical and human dimensions were considered, but presented as separate entities (DeStefano and Deblinger 2005). In fact, an explicit assumption was that human-wildlife conflict was directly influenced by population size, and management for stable wildlife populations will minimize potential for human-wildlife conflict (DeStefano and Deblinger 2005).

Indicators derived from social science also focus on wildlife population size as an independent variable. Metrics such as the sociological carrying capacity (Decker et al. 1985) have been used to understand the diversity of stakeholder viewpoints related to wildlife management. For instance, cultural carrying capacity is the population size that relates to a management-desired level of activity at a given time (Minnis and Peyton 1985). Wildlife acceptance capacity (WAC) also describes a desired wildlife population size at a given point of time, which can vary across stakeholder groups with management effort focused on the group of greatest concern (Decker and Purdy 1988). Building on WAC, wildlife stakeholder acceptance capacity considers both positive and negative effects of a species and its population size on multiple stakeholder groups in an attempt to maximize net social value across stakeholders (Carpenter et al. 2000). Adaptive impact management (AIM) further focuses on wildlife-related impacts and stakeholder values within an adaptive management framework (Riley et al. 2002). Regardless of metrics, ecological and social frameworks consistently describe wildlife population size as a primary driver of human-wildlife interactions leading to conflict.

Fewer conceptual frameworks have integrated ecological and social factors that affect human-wildlife interactions. Kennedy 
and Thomas (1995) used human-wildlife examples to describe natural resource values as interactions among four systems: natural environment, social, economic, and political. More specific to wildlife, Liu et al. (1999) described interrelationships and feedbacks among natural, ecological, human, and policy variables as drivers impacting giant panda habitat. Liu et al. (1999) did not incorporate the specific social metrics (e.g., WAC) described above. However, a systems approach allowed them to evaluate potential effects of multiple policy scenarios on human population growth and behavior, e.g., timber and fuelwood consumption, and how those behaviors may impact habitat at the landscape level (Liu et al. 1999). Although such examples begin to describe human-wildlife linkages, there is a need to better understand feedbacks among wildlife, human behavior, and landscapes within coupled human and natural systems.

Our objective was to use examples from past research, with particular focus on urban systems where available, to describe a conceptual framework for human-wildlife interactions within coupled human and natural systems. Past research has investigated many of the individual relationships that we present within the framework, but formal integration of those relationships has not yet been presented. Included in this discourse is our own ongoing study of urban rodent control behavior (Morzillo and Mertig $2011 a, b$, Morzillo and Schwartz 2011), which serves as an impetus for this discussion. Similar to the aforementioned frameworks, results from our rodent control study suggest that both species population size and human changes to habitat play a role in human-wildlife relationships.

We begin our discussion with wildlife-related events and human reaction to them. Like AIM (Riley et al. 2002), relationships between humans and wildlife may not be dependent upon population size per se, but rather are driven initially and simply by an event related to species presence, or any population size of $n \geq 0$. For simplicity, we refer to conflict as human-wildlife interactions perceived by humans as negative. That conflict is the result of a wildlife-related tangible event, which leads to an impact driven by a human reaction resulting in a particular human behavior. Building upon AIM (Riley et al. 2002), we postulate that each impact, conflict, and resulting behavior may reinforce and enhance both positive and negative perceptions of wildlife by humans and, therefore, both positive and negative outcomes for wildlife depending on the particular wildlife-related event. We describe how those impacts, conflicts, and behaviors are neither simple nor isolated. Rather, they are complex mechanisms that are influenced by and integrated within broader ecological and social processes and feedbacks across landscapes. Finally, we describe our ongoing work on human behaviors related to urban rodent control that is exploring hypotheses related to landscapelevel feedbacks demonstrated in this framework.

\section{CONCEPTUAL FRAMEWORK}

An impact, positive or negative, is the result of a wildlife-related event that causes a human reaction (Fig. 1a; Riley et al. 2002) and results in a particular human behavior (Fig. 1b). Both the human reaction to an event (positive versus negative) and the resulting behavior from an impact affect wildlife, e.g., decisions about pest control (Morzillo and Mertig $2011 a, b$ ), and are influenced by complex interactions among human characteristics (Fig. 1c), such as environmental values and value orientations (e.g., Fulton et al. 1996, Riley et al. 2002, Zinn and Pierce 2002, Kaltenborn et al. 2012), attitudes toward wildlife (e.g., Morzillo et al. 2007, Krester et al. 2009a, McDonald et al. 2012, Urbanek et al. 2013), interest in seeing wildlife (e.g., Morzillo et al. 2007), attitudes toward particular species (e.g., Daniels and Kirkpatrick 2011), risk perception (Gore et al. 2007), and other cognitive and motivational variables (Fulton et al. 1996, Whittaker et al. 2001, Baruch-Mordo et al. 2011, Luther 2013). Collectively, these constructs influence and interact with each other, i.e., feedbacks, to form the basis for human cognitive and motivational perceptions and dynamics of human-wildlife relationships, i.e., "impact-based feedbacks" (e.g., Manfredo et al. 2009, Decker et al. 2012), and drivers of wildlife management as part of environmental policy (Fig. 1d; e.g., Mattson and Ruther 2012, Pincetl 2013).

Fig. 1. Conceptual framework for evaluating human-wildlife interactions and feedbacks in a coupled human and natural system. Arrows indicate unidirectional (single arrows) and bidirectional (double arrows) interactions and feedbacks between system components and characteristics. Relationships described in the text are as follows: (a) a wildlife related event plus a human reaction results in an impact; (b) impacts can influence human behavior; (c) individual human characteristics can influence reactions and behaviors; (d) human behaviors serve as drivers of wildlife management and policy; (e) human behavior resulting in an impact could have direct and (f) indirect feedbacks that affect wildlife; ( $\mathrm{g}$ ) changes to the landscape as a result of human behaviors occur across multiple scales; (h) land use affects landscape characteristics; (i) environmental policy limits human behavior for the benefit of humans and other species. Letters a-d correspond to impactbased feedbacks. Letters e-g correspond to behavior-based feedbacks. Letters g-i correspond to landscape-based feedbacks. Letters a-c and g-h correspond to components and feedbacks traditionally considered parts of the "human system" and "natural system," respectively, with d-f and i representing linkages between them.

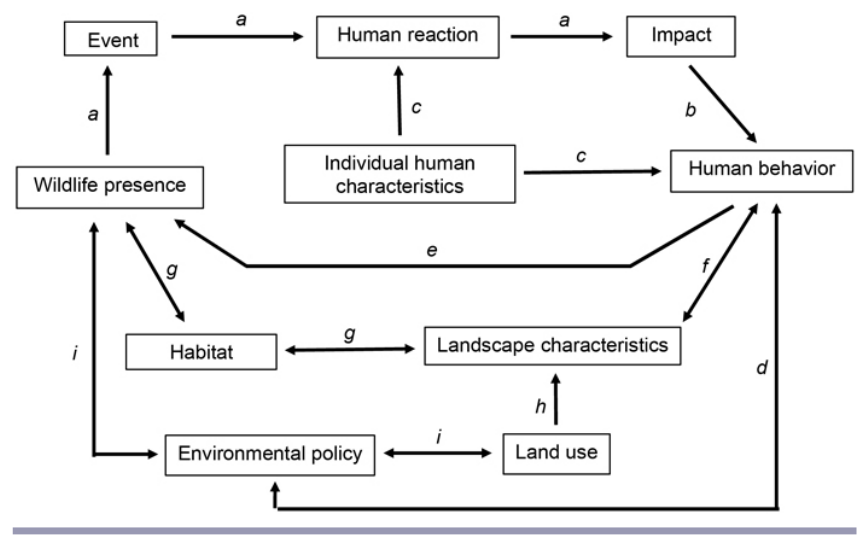

Impact-based feedbacks (Fig. 1a-d) influence human behaviors directly or indirectly related to physical contact between humans and wildlife, i.e., "behavior-based feedbacks." Direct behaviorbased feedbacks occur if a human physically observes an animal. 
In contrast, indirect behavior-based feedbacks may be more circuitous, and exist as evidence of wildlife, such as feces, damaged surfaces from chewing, nesting materials, or landscaping damage from foraging, digging, or tunneling activity. Other factors that influence behaviors include context (Koval and Mertig 2004), wildlife species (Wittmann et al. 1998), frequency of interactions with wildlife (Krester et al. 2009a), extent of damage (MartínezEspiñeira 2006, Morzillo and Mertig 2011a), and perceived risk (Needham et al. 2004, Batt 2009). In cases of both direct and indirect impacts, resulting human behavior may influence ongoing animal presence. Killing an animal results in elimination of current and future events by that individual animal (Fig. 1e), although other individual animals could later inhabit the location and provoke future conflict. Alternatively, scaring an animal or fixing a habitat-based object of the impact, e.g., filling a burrow with soil or replanting eaten ornamental vegetation, may result in only a temporary resolution, with potential for the animal to return and initiate new events that lead to further impacts. In that case, humans actively physically alter landscape characteristics (Fig. 1f, g). Whether those human behaviors affect wildlife positively or negatively depends on a human's motivation for contact.

Behavior-based feedbacks, direct or indirect (Fig. 1e-g) drive feedback loops with either positive or negative consequences for wildlife. If the human perception of an impact is positive, resulting human behaviors may encourage ongoing wildlife presence. For example, behaviors such as feeding birds and other species and planting particular types of vegetation often are used to attract and observe wildlife, and create habitat (e.g., Lepczyk et al. 2004a, Horn and Johansen 2013), even in cases in which perceived positive motivations result in negative impacts on wildlife, e.g., feeding animals "people food." Conversely, if human perception of the impact is negative, resulting human behaviors may deter or eliminate wildlife presence. For example, humans may make landscape changes in attempt to repel wildlife, e.g., deer, from vegetation and other features (e.g., Barras and Seamans 2002, Gilsdorf et al. 2002, Rondeau and Conrad 2003, Krester et al. 2009b). Other methods include guidance, enforcement, and monitoring as mechanisms to change human behavior and minimize human-wildlife conflict, which may or may not be successful over time (Baruch-Mordo et al. 2011). Regardless, as perceived by wildlife, those human-induced landscape changes will determine the return of an animal to the location of the event (Fig. 1g). It is also possible that human behaviors initiated to benefit wildlife, as perceived by humans, can later be perceived as negative feedbacks. For example, efforts to attract birds may also attract potentially unwanted species, such as black bears (e.g., Merkle et al. 2013). Consequently, if human-based landscape changes do not successfully eliminate future wildlife-related events, humans may change their behavior to result in a direct effect, e.g., mortality (Fig. 1e). Therefore, feedbacks resulting from wildlife-related events and interactions may vary over time.

Impact- and behavior-based feedbacks that take place at the fine scale are components of larger systems, and influenced by landscape-level processes, i.e., "landscape-based feedbacks." In our framework, such landscape-based feedbacks include land uselandscape characteristic interactions, and influence mechanisms by which natural and social components interact, creating cross- scale feedback dynamics. Land use affects landscape characteristics (e.g., Turner et al. 2001, Hendrickx et al. 2007, Grimm et al. 2008, Millington et al. 2010). For example, urbanization influences landscape pattern and process (McDonnell et al. 1997, Luck and Wu 2002), and leads to landscapes that are very different ecologically from what existed prior to urbanization. For example, tree cover in Oakland, California, has increased from 2 to $19 \%$ since preurbanization as a result of conversion of grass-, shrub-, and marshlands to trees interspersed among development (e.g., Nowak 1993). Such changes across multiple scales may enhance features that serve as enticing resources for wildlife. In turn, those features increase potential for wildlife-related events (Fig. 1h), which vary between species and development patterns (Krester et al. 2008). In fact, habitat change is among the greatest challenges to urban wildlife management (DeStefano and DeGraaf 2003), as variation in vegetation and development characteristics influence urban wildlife composition (Theobald 2004, Fraterrigo and Wiens 2005, McKinney 2008) and potential for conflict and resulting human behavior (Morzillo and Schwartz 2011).

Trends in biodiversity and other ecosystem processes have been described for urban landscapes (e.g., Blair 2004, McKinney 2008). Our research suggests that human-wildlife interactions and feedbacks may follow similar patterns (Morzillo and Schwartz 2011). Basic resource needs, e.g., cover, food, and water, must be present in a location for it to be considered suitable habitat; conditions of those resources influence wildlife presence (Fig. 1g). In urban landscapes, humans and wildlife share limited space and, therefore, overlap in resource use, i.e., habitat, is likely. As a result, both humans and wildlife often perceive many of the same resources as attractive (e.g., O'Donnell and DeNicola 2006). For example, particular vegetation types commonly used in landscaping can be attractive to wildlife because of nutritional quality and/or availability (Nielsen and Porter 2011). Our own research suggests that nonnative vegetation, e.g., fruit trees, may provide cover and food alternatives to "natural" vegetation, and influence relationships between landscape characteristics, human-wildlife conflict, and specific species (Morzillo and Schwartz 2011; Steinberg et al., in press). Thus, human decisions about landscape characteristics can result in attracting wildlife, and be iterative if humans reinforce those characteristics following wildlife-related events (Leong 2009). Although quantifying such hypothesized feedback loops is beyond the scope of this paper, potential for evaluation of such linkages exists (e.g., VerCauteren et al. 2006, Burghardt et al. 2009, Harris et al. 2012).

Concurrent use of resources by both humans and wildlife, and resulting conflict, affect landscape and habitat quality, from both human and wildlife perspectives, respectively, and lead to lethal consequences for wildlife (Morzillo and Mertig 2011b). Further investigation will enhance our understanding of how development configurations, landscaping schemes, and policies that prescribe land use may inadvertently drive linkages between broad-scale and fine-scale impacts (Fig. 1h, i). The desire to protect wildlife habitat and human health has resulted in localto-global policy limiting human behavior that causes harm to wildlife and humans (Fig. 1i). Thus, regulating human behavior 
detrimental to wildlife in turn may influence quality of habitat resources.

\section{URBAN RODENT CONTROL AND LANDSCAPE-LEVEL FEEDBACKS: FIRST STEPS}

Our results to-date (Morzillo and Mertig $2011 a, b$, Morzillo and Schwartz 2011) and our conceptual framework served as starting points for ongoing exploration of this human and natural system. Although numerous possible research trajectories exist, we have selected two new hypotheses focused on particular components and feedbacks to serve as pilot analyses. The first hypothesis is that fine-scale landscape characteristics affect spatial variation of control behavior (Fig. 1a-g). The second hypothesis is that land-use history influences landscape characteristics that drive control behavior (Fig. 1h). Both hypotheses assess multiscale linkages between impact-, behavior-, and landscape-based feedbacks.

Our study area includes two urban areas in California: (1) the southwest section of Bakersfield, and (2) in proximity to the Santa Monica Mountains National Recreation Area (SAMO; Fig. 2). Bakersfield is a city of approximately 350,000 in the southern end of the San Joaquin Valley (Kern County). SAMO straddles the border of eastern Ventura and western Los Angeles Counties, and contains an interspersed mix of public open space and suburban and exurban development (see Morzillo and Schwartz [2011] for detailed description of the study areas). In both locations, local biologists have observed nontarget impacts of rodent control products as contributing to mortality of several species (Riley et al. 2007, McMillin et al. 2008). Rodent control products, "rodenticides," are specifically manufactured to target rodents, e.g., mice, rats, family Muridae, and exist among a variety of trade names and brands. Of specific interest to this study are anticoagulants, with active chemical ingredients including brodifacoum, bromadiolone, and warfarin, and they inhibit the clotting of blood (Amdur et al. 1991). Thus, there is a direct link between this topic and policy for use of toxic substances.

Fig. 2. Study areas in California, USA, used for evaluation of urban rodent control behavior (adapted from Morzillo and Mertig $2011 b$ and Morzillo and Schwartz 2011).

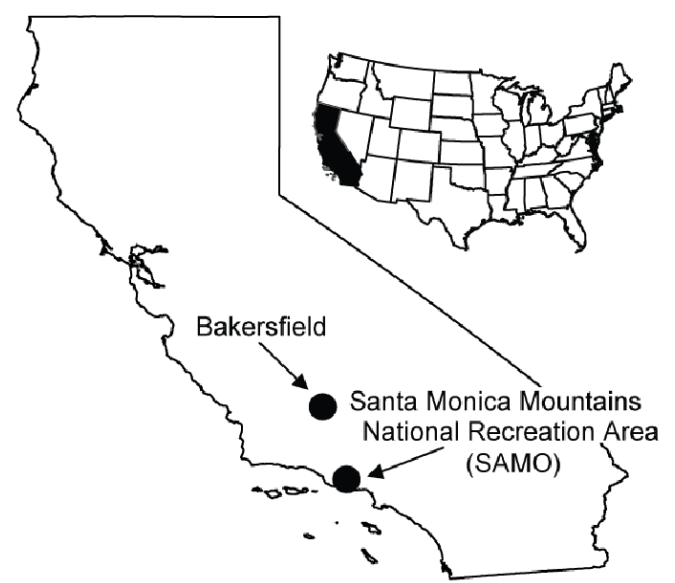

In 2007, a mail survey was used to obtain information about resident pest control behavior within the study areas $(n=2001$; Bakersfield 780; SAMO = 1221). Morzillo and Mertig $(2011 a, b)$ provide further details about survey mailing, returns, and analysis of human dimensions data. We used ArcGIS 9.3.1 (Environmental Systems Research Institute, Redlands, California, USA) and spatial statistics to evaluate relationships between residential rodent control behavior and urban landscape variables (Morzillo and Schwartz (2011). Results of those works have allowed us to begin to describe interrelationships within our conceptual framework:

1. Wildlife-related events (Fig. 1a): Outdoor observation of pest species was the most common reason for control behavior in both study areas, followed by indoor observation of pests, damage to landscaping, and property damage (Morzillo and Mertig 2011a).

2. Individual human characteristics influence reactions and behaviors (Fig. 1a-c): Attitudes toward rodents were relatively negative (Morzillo and Mertig 2011a). Results suggested that humans may be making cognitive linkages between personal interactions with rodents and household or individual welfare (Morzillo and Mertig 2011a), with demographic relationships influencing reactions and behaviors as well (Morzillo and Mertig 2011a,b). In fact, preliminary results suggested that relationships between attitudes toward rodents and control behavior are converse to general trends in the human dimensions literature, i.e., people with positive attitudes toward wildlife are less likely to participate in behaviors related to negative consequences for wildlife (A. T. Morzillo, unpublished manuscript). Therefore, additional psychological and/or motivational constructs beyond attitudes toward wildlife, e.g., risk perception (Batt 2009), likely influence human reaction to pests and resulting behavior.

3. Impact-influenced behavior (Fig. 1b): Small sample sizes and infrequent and/or irregular occurrence can make the study of human-wildlife interactions difficult. Approximately half of respondents indicated participation in rodent control behavior, and many of those respondents used both physical and chemical products (Morzillo and Mertig 2011a). Ubiquitous distribution of rodent control behavior across the landscape allowed for spatial evaluation across multiple scales (Morzillo and Schwartz 2011).

4. Presence of species affected (Fig. 1-e): Mice, rats, squirrels, and gophers were among the species most frequently targeted by respondents, i.e., presence drives reaction and impact, as were several nonrodent species, ranging from bats to cats to skunks and opossums (Morzillo and Schwartz 2011). In addition, nontarget impacts have affected several large mammals that also inhabit the area and may feed on toxic rodents, including bobcat (Lynx rufus), coyote (Canis latrans), mountain lion (Puma concolor), and San Joaquin kit fox (Vulpes macrotis mutica; Riley et al. 2003, 2007, McMillin et al. 2008). Such occurrences provide evidence of possible pathways for contact between rodent control products and wildlife, although causal linkages are beyond the scope of data collected thus far. Few respondents reported awareness of potential for nontarget impacts (Morzillo and Mertig 2011b). 
Fig. 3. (a) Land cover classification and (b) the percentage of trees (green) and the percentage of impervious surface (purple) for the Bakersfield study area. High percentages of trees are distributed across residential portions of the study area in parks and golf courses.
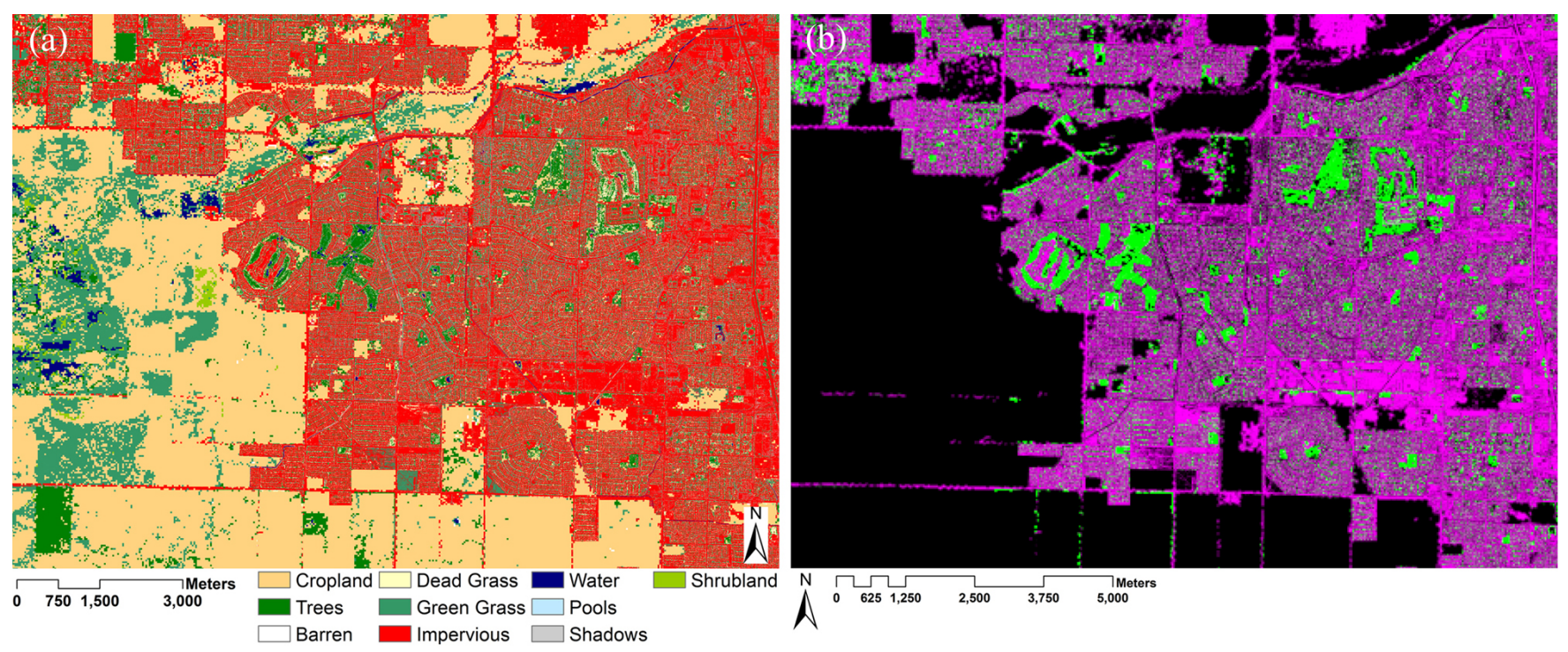

5. Landscape linkages (Fig. 1f-h): Variation in control behavior existed in relation to development density and distance from natural areas (Morzillo and Schwartz 2011), and contrasted earlier findings evaluating pest control and domicile type (Berkowitz et al. 2002) and urban versus rural pest control (Adgate et al. 2000). In addition, spatial statistics allowed us to identify the scale at which rodent control behavior was autocorrelated, and uncover evidence of clusters of control behavior (Morzillo and Schwartz 2011).

6. Relevance to policy (Fig. 1d, i): A 2008 U.S. Environmental Protection Agency (EPA) federal ruling now limits the sale and distribution of 10 anticoagulant rodenticide products in the U.S. (US EPA 2008). New requirements include minimum package size, and restrictions on locations of use, sale, and distribution, and mandated use of bait stations for outdoor above-ground application (US EPA 2008). Our research began prior to the 2008 ruling.

Our first hypothesis (fine-scale landscape characteristics may affect spatial variation in control behavior) explores linkages between human behavior, landscape characteristics, habitat, and wildlife presence (Fig. 1f, g). As a first step to this analysis, we used remote-sensing data to assess details about landscape characteristics, particularly the distinction between vegetation and nonvegetation, i.e., impervious surface. A 1-m land cover classification was created for both study areas using National Agricultural Imagery Program (NAIP) images collected in springsummer 2012. A supervised maximum likelihood classification was run on the four original image bands (R, B, G, NIR), a Normalized Difference Vegetation Index (NDVI) layer, and three texture measures (mean, variance, and entropy; Lillesand and Kiefer 2000). The classifications were created using approximately 3000 training samples identified with 2D spectral scatter plots for each class and each region. Classes included impervious surface/ barren, trees, green grass, dead grass, grassland, water, swimming pools, and shadows. The U.S. Department of Agriculture cropland data layer was used to indicate cropland for Bakersfield. For SAMO, a water body layer from the National Hydrography Dataset was used as a mask for accuracy assessment between the water and shadow classes. Accuracy was assessed using ground observations based on Google Earth imagery: approximately 800 observations for Bakersfield and 1000 for SAMO. The kappa coefficient $(\mathrm{K})$ was used to measure pairwise agreement, correcting for expected chance agreement (Rosenfield and Fitzpatricklins 1986), with a range between 0 (no agreement other than that expected by chance) and 1 (total agreement; Lunetta et al. 1991); $\mathrm{K}>0.8$ represent strong agreement. Classification accuracy was satisfactory for further analysis (Bakersfield: overall accuracy $=90 \%, \mathrm{~K}=0.89$; SAMO: overall accuracy $=89.7 \%$; $=0.88$ ). Based on the land cover classifications described above, we calculated the percentage of nonimpervious surface and the percentage of trees in $30 \mathrm{~m}$ by $30 \mathrm{~m}$ blocks. We used these data to determine where impervious surfaces were prominent in contrast to vegetation.

Morzillo and Schwartz (2011) suggested that "hotspots" for rodent control behavior were associated with particular land uses, e.g., low density development such as golf courses, thought to contain more tree cover and luscious vegetation that may attract wildlife than surrounding areas. For example, golf courses contain features, e.g., trees, water, associated with positive outcomes for wildlife (Warnken et al. 2001), although use by wildlife varies by species and landscape context (e.g., White and Main 2005, Jones et al. 2005). In Bakersfield, impervious surface was the dominant land cover class in some parts of the study area (up to $100 \%$ in some $30 \mathrm{~m}$ by $30 \mathrm{~m}$ blocks), particularly in the east toward the city center, and in the industrial north and south (Fig. $3 a, b)$. Golf courses in the central and western portions of the 
Fig. 4. (a) Land cover classification and (b) the percentage of trees (green) and the percentage of impervious surface (purple) for the Santa Monica Mountains National Recreation study area. Higher percentages of trees correspond with development, riparian corridors, and north-facing slopes. High impervious surfaces are found in residential areas in the south and west.
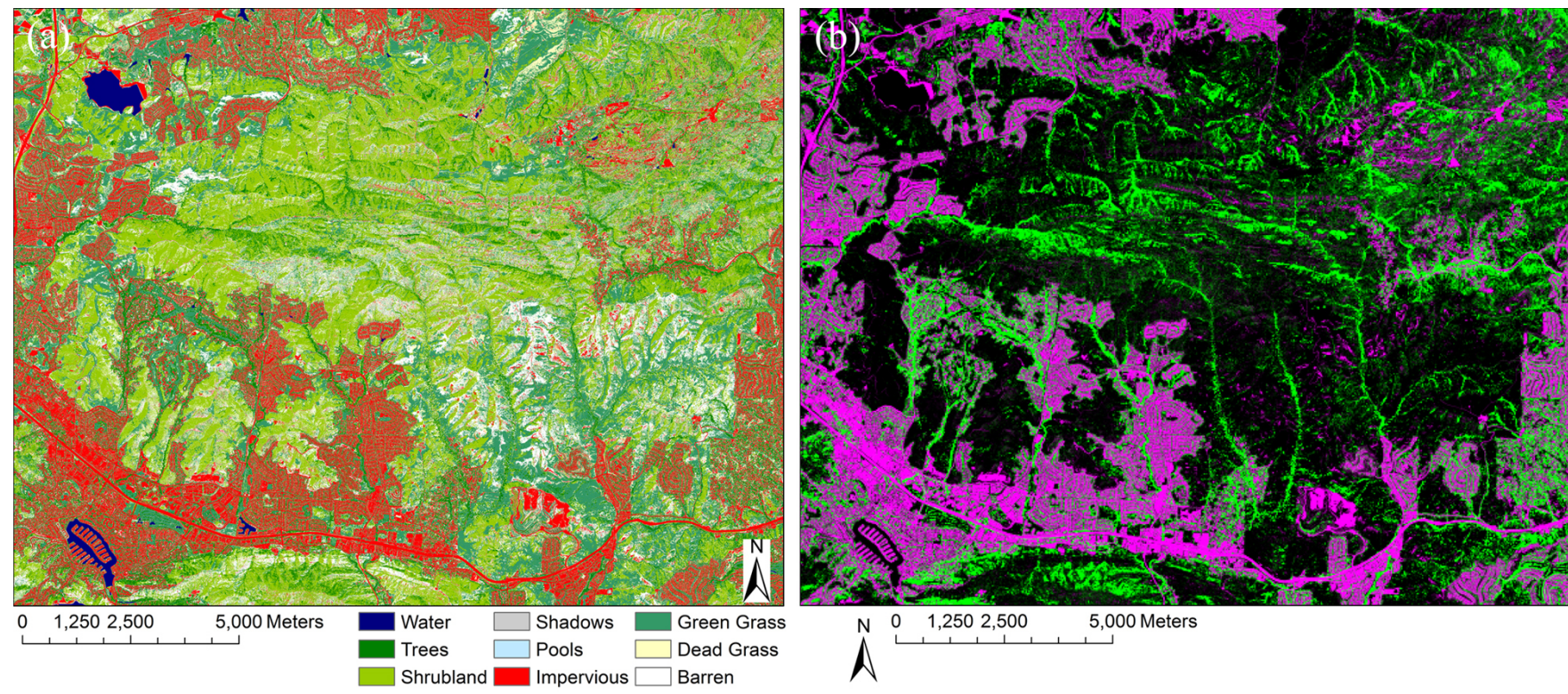

study area were the most concentrated sources of trees and green vegetation that might be attractive to wildlife; urban parks also were prominent (Fig. 3a, b). Small areas of trees and green vegetation were evenly distributed across residential areas, particularly among relatively low-density development of the west. Impervious surface was less evenly distributed in SAMO, an area dominated by shrubland and grassland interspersed among developed areas (Fig. 4a). The highest percentages of trees corresponded with low-density development and riparian corridors (Fig. 4b). In both locations, "hot-spots" of control corresponded to areas of mixtures of trees and impervious surfaces where the density of impervious surfaces was lower and the density of trees was higher than in other parts of the study areas. For SAMO, greatest contrast also illuminated boundaries between "natural" chaparral vegetation and extensive change as a result of landscaping in residential areas.

Preliminary analysis supports our first hypothesis (fine-scale landscape characteristics affect spatial variation of control behavior; Fig. 1f, g), and our investigation is ongoing. Future plans include application of additional ecological metrics to link ecological and social data with particular focus on landscape contrasts, such as between natural and landscaped vegetation and between vegetation and impervious areas. For example, edge contrast has been described as a "universal" metric to describe landscape structure (Cushman et al. 2008). Importance of edge contrast varies across scales and may be less important for wildlife than more complex measures of heterogeneity, interactions among multiple metrics, or fragmentation (e.g., Hansson et al. 1995, Bolger et al. 2000, Kie et al. 2002, Rodewald 2002). However, few studies exist on edge contrasts for relatively small wildlife species in chaparral habitats (e.g., Langen et al. 1991, Crooks and Soulé 1999, Bolger et al. 2000) as compared to forests (Chalfoun et al. 2002).
Results from our first hypothesis led us to a second hypothesis suggesting that land use history also may influence landscape characteristics that drive control behavior (Fig. 1f, g, h). As a first step to this analysis, we assembled time-series of orthophotos to visually evaluate the urbanization process within our study areas (land use affects landscape characteristics; Fig. 1-h). However, only preliminary results for Bakersfield are described here. For Bakersfield, available black and white images were available from June 1994, with a spatial resolution of one meter, in addition to the colored images from 2010. In 1994, most of the area that corresponded with the current Bakersfield hot-spot was in agricultural use or in initial stages of conversion from agriculture to urban, including a current golf course (Fig. 5). Thus, within the past 20 years, land use within the hot-spot area may have included extensive use of fertilizers and other products that today still influence characteristics and quality of current vegetation. Research focused on legacy of exarable land suggests that characteristics that promote different vegetation-soil relationships than those that exist for native communities on such land can be maintained for decades (e.g., Steenwerth et al. 2002, Kulmatiski and Beard 2008). Thus, we look forward to our nascent examination in this direction.

\section{CONCLUSION}

Research beyond our pilot hypotheses will be necessary to fully explore feedbacks among our human-wildlife interaction framework. Future hypotheses and expansion of this work will include components of the conceptual model not addressed in detail here. For example, we suspect that landscape characteristics appealing to wildlife may also be those that are appealing to humans (Fig. 1f). Research suggests that human preferences for particular vegetation characteristics exist in both natural and urban settings (e.g., Ulrich 1986). Large mature trees and parks with trails and natural areas were identified as "important" near 
Fig. 5. Time-series orthophotos of an example portion of the Bakersfield study area in (a) 1994 and (b) 2010. In this example, much of the area observed as developed in 2010 was in initial stages of development or still in agricultural use in 1994.

a

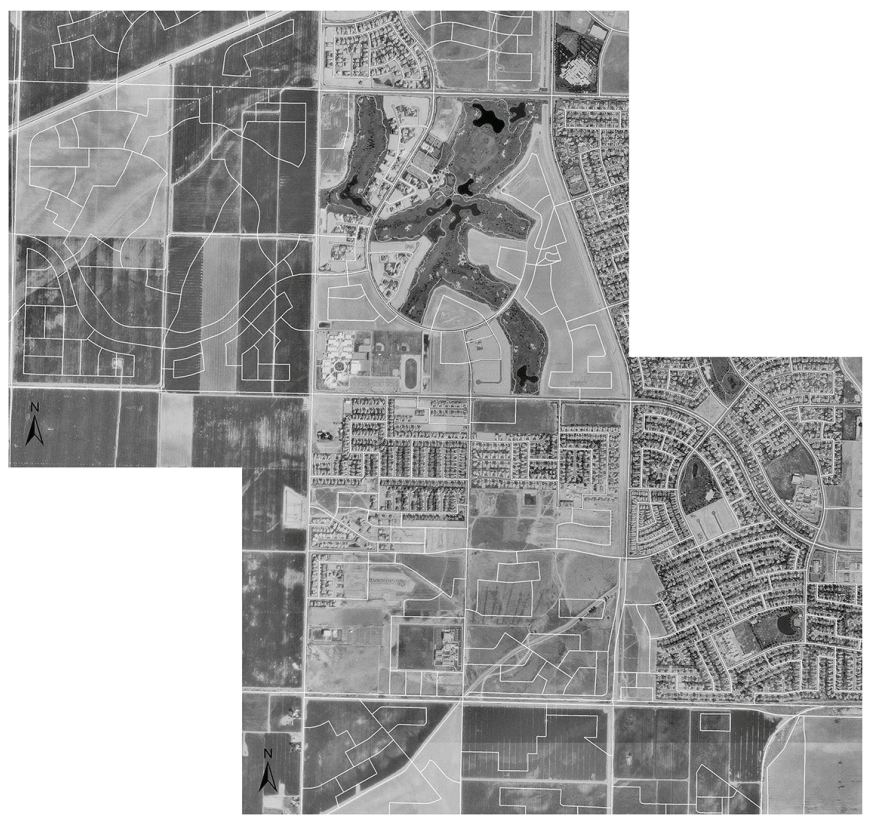

b

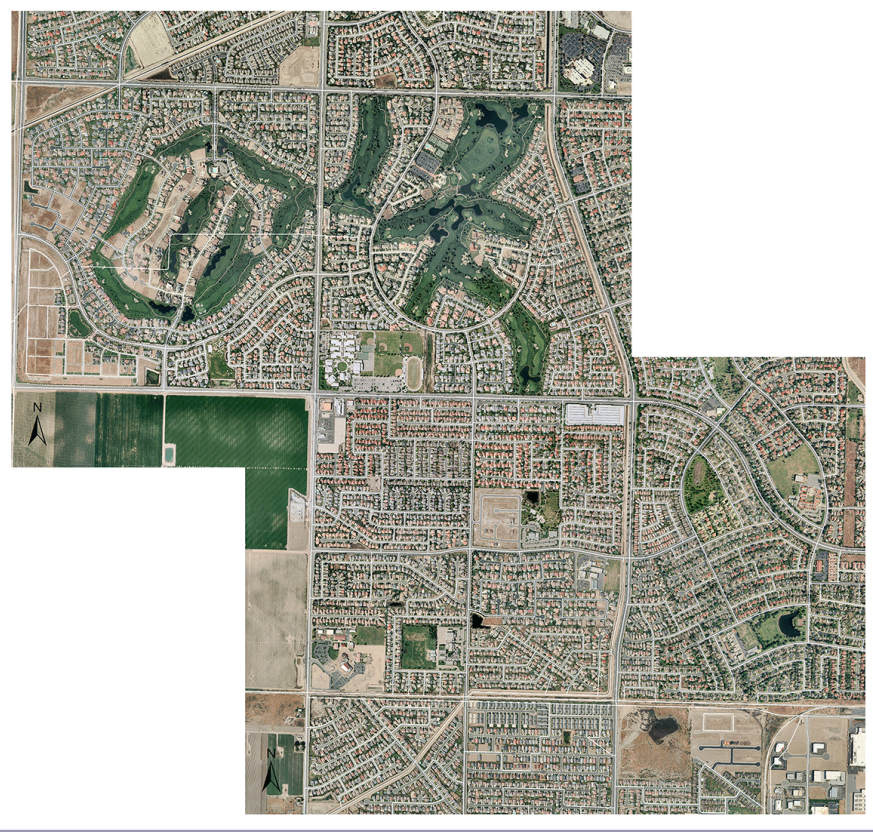

the homes and neighborhoods of a majority of residents surveyed within the Portland-Vancouver metropolitan area (A. T. Morzillo, unpublished manuscript). In fact, urban vegetation and related metrics also have been linked to relationships with housing value (e.g., Mansfield et al. 2005) and quality of life (e.g., Sheets and Manzer 1991, Dwyer et al. 1992, Jensen et al. 2004). However, less is known about how human-wildlife interactions may influence human perception of landscape characteristics, or drive human behaviors that directly alter landscape characteristics.

We also suspect that land use planning in our study areas reflect landscape characteristics that are appealing to humans, and characteristics of those features influence wildlife-related events. This has been discussed to some extent in preceding paragraphs. In addition, several studies have suggested strong linkages between socioeconomics, plant diversity, and vegetation used for landscaping in urban areas (e.g., Hope et al. 2003, Martin et al. 2004, Luck et al. 2009). Such relationships have been postulated for control behavior trends observed in our study (Morzillo and Schwartz 2011). Although rodent pest issues often are associated with particular socioeconomic characteristics such as overcrowding and low incomes (e.g., Jassat et al. 2013), casual observation suggests that areas of concentrated control behavior may coincide with particularly affluent portions of both study areas (A. T. Morzillo, unpublished manuscript), but this has not yet been measured quantitatively for either location. Accordingly, we suggest that future application of this model to other locations pay attention to socioeconomic heterogeneity within study areas, recognize the complexity of linkages within the framework, and synthesize these linkages across the coupled human and natural system. We also have yet to explore local land-use laws and zoning restrictions for both study areas and their potential to influence landscape characteristics and feedbacks that may influence landscape use by wildlife.

Our results to-date suggest evidence that human-wildlife interactions are influenced by both fine- and coarse-scale feedbacks across landscapes. Thus, our emerging framework provides insight into how broad landscape characteristics and feedbacks may serve as important components that interact with impact-level feedbacks between humans and wildlife among coupled human and natural systems. Past research focused on population size is a logical approach to the evaluation of humanwildlife conflict and managing wildlife populations. However, our research supports a broader story that may lead to a more thorough understanding of ecosystem and landscape dynamics between humans and wildlife and feedbacks among them.

Responses to this article can be read online at: http://www.ecologyandsociety.org/issues/responses. $\mathrm{php} / 6883$

\section{Acknowledgments:}

We thank B. Cypher, A. Fairbrother, V. Hull, D. Kamradt, J. Liu, A. G. Mertig, D. Olszyk, S. P. D. Riley, R. Sauvajot, M. Tuanmu, six anonymous reviewers who provided constructive suggestions for improving this manuscript, and all of the California residents who participated in the initial phase of this research. 


\section{LITERATURE CITED}

Adgate, J. L., A. Kukowski, C. Stroebel, P. J. Shubat, S. Morrell, J. J. Quackenboss, R. W. Whitmore, and K. Sexton. 2000. Pesticide storage and use patterns in Minnesota households with children. Journal of Exposure Analysis and Environmental Epidemiology 10:159-167. http://dx.doi.org/10.1038/sj.jea.7500078

Amdur, M. O., J. Doull, and C. D. Klaassen. 1991. Casarett and Doull's toxicology: the basic science of poisons. Fourth edition. Pergamon Press, New York, New York, USA.

Barras, S. C., and T. W. Seamans. 2002. Habitat management approaches for reducing wildlife use of airfields. Staff Publications. Paper 463. USDA National Wildlife Research Center, University of Nebraska, Lincoln, Nebraska, USA. [online] URL: http:// digitalcommons.unl.edu/icwdm usdanwrc/463

Baruch-Mordo, S., S. W. Breck, K. R. Wilson, and J. Broderick. 2011. The carrot or the stick? Evaluation of education and enforcement as management tools for human-wildlife conflicts. PLOS one 6:e15681. http://dx.doi.org/10.1371/journal.pone.0015681

Batt, S. 2009. Human attitudes towards animals in relation to species similarity to humans: a multivariate approach. Bioscience Horizons 2:180-190. http://dx.doi.org/10.1093/biohorizons/hzp021

Berkowitz, G. S., J. Obel, E. Deych, R. Lapinski, J. Godbold, Z. Liu, P. J. Landrigan, and M. S. Wolff. 2002. Exposure to indoor pesticides during pregnancy in a multiethnic, urban cohort. Environmental Health Perspectives 111:79-84.

Blair, R. 2004. The effects of urban sprawl on birds at multiple levels of biological organization. Ecology and Society 9(5): 2. [online] URL: http://www.ecologyandsociety.org/vol9/iss5/art2/

Bolen, E. G., and W. L. Robinson. 1999. Wildlife ecology \& management. Fourth edition. Prentice-Hall, Upper Saddle River, New Jersey, USA.

Bolger, D. T., A. V. Suarez, K. R. Crooks, S. A. Morrison, and T. J. Case. 2000. Arthropods in urban habitat fragments in southern California: area, age, and edge effects. Ecological Applications 10:1230-1248. http://dx.doi.org/10.1890/1051-0761(2000)010[1230: AIUHFI]2.0.CO;2

Burghardt, K. T., D. W. Tallamy, and W. G. Shriver. 2009. Impact of native plants on bird and butterfly biodiversity in suburban landscapes. Conservation Biology 23:219-224. http://dx.doi. org/10.1111/j.1523-1739.2008.01076.x

Carpenter, L. H., D. J. Decker, and J. F. Lipscomb. 2000. Stakeholder acceptance capacity in wildlife management. Human Dimensions of Wildlife 5:5-19. http://dx.doi.org/10.1080/108712$\underline{00009359184}$

Chalfoun, A. D., F. R. Thompson, III, and M. J. Ratnaswamy. 2002. Nest predators and fragmentation: a review and metaanalysis. Conservation Biology 16:306-318. http://dx.doi. org/10.1046/j.1523-1739.2002.00308.X

Crooks, K. R., and M. E. Soulé. 1999. Mesopredator release and avifaunal extinctions in a fragmented system. Nature 400:563-566. http://dx.doi.org/10.1038/23028

Cushman, S. A., K. McGarigal, and M. C. Neel. 2008. Parsimony in landscape metrics: strength, universality, and consistency.
Ecological Indicators 8:691-703. http://dx.doi.org/10.1016/j. ecolind.2007.12.002

Daniels, G. D., and J. B. Kirkpatrick. 2011. Attitude and action syndromes of exurban landowners have little effect on native mammals in exurbia. Biodiversity and Conservation 20:3517-3535. http://dx.doi.org/10.1007/s10531-011-0139-4

Decker, D. J., T. L. Brown, and G. F. Mattfeld. 1985. Deer population management in New York: using public input to meet public needs. Pages 185-196 in S. L. Beasom and S. F. Roberson, editor. Game harvest management: a Proceedings of the Third International Symposium of the Caesar Kleberg Wildlife Research Institute, 3-6 October 1983, Texas A\&I University, Kingsville, Texas, USA.

Decker, D. J., and K. G. Purdy. 1988. Toward a concept of wildlife acceptance capacity in wildlife management. Wildlife Society Bulletin 16:53-57.

Decker, D. J., S. J. Riley, and W. F. Siemer. 2012. Human dimensions of wildlife management. Second edition. John Hopkins University Press, Baltimore, Maryland, USA.

DeStefano, S., and R. D. Deblinger. 2005. Wildlife as valuable natural resources versus intolerable pests: a suburban wildlife management model. Urban Ecosystems 8:179-190. http://dx.doi. org/10.1007/s11252-005-4379-5

DeStefano, S., and R. M. Degraaf. 2003. Exploring the ecology of suburban wildlife. Frontiers in Ecology and the Environment 1:95-101. http://dx.doi.org/10.1890/1540-9295(2003)001[0095:ETEOSW] 2.0.CO;2

Dwyer, J. F., E. G. McPherson, H. W. Schroeder, and R. A. Rowntree. 1992. Assessing the benefits and costs of the urban forest. Journal of Arboriculture 18:227-234.

Faeth, S. H., P. S. Warren, E. Shochat, and W. A. Marussih. 2005. Trophic dynamics in urban communities. BioScience 55:399-407. http://dx.doi.org/10.1641/0006-3568(2005)055[0399:TDIUC]2.0. $\mathrm{CO} ; 2$

Foster, M. L., and S. R. Humphrey. 1995. Use of highway underpasses by Florida panthers and other wildlife. Wildlife Society Bulletin 23:95-100.

Fraterrigo, J. M., and J. A. Wiens. 2005. Bird communities of the Colorado Rocky Mountains along a gradient of exurban development. Landscape and Urban Planning 71:263-275. http:// dx.doi.org/10.1016/j.landurbplan.2004.03.008

Fuller, R. A., P. H. Warren, P. R. Armsworth, O. Barbosa, and K. J. Gaston. 2008. Garden bird feeding predicts the structure of urban avian assemblages. Diversity and Distributions 14:131-137. http://dx.doi.org/10.1111/j.1472-4642.2007.00439.x

Fulton, D. C., M. J. Manfredo, and J. Lipscomb. 1996. Wildlife value orientations: a conceptual and measurement approach. Human Dimensions of Wildlife 1:24-47. http://dx.doi. org/10.1080/10871209609359060

Gilsdorf, J. M., S. E. Hygnstrom, and K. C. VerCauteren. 2002. Use of frightening devices in wildlife damage management. Integrated Pest Management Reviews 7:29-45. http://dx.doi. org/10.1023/A:1025760032566 
Gore, M. L., B. A. Knuth, P. D. Curtis, and J. E. Shanahan. 2007. Factors influencing risk perception associated with human-black bear conflict. Human Dimensions of Wildlife 12:133-136. http:// dx.doi.org/10.1080/10871200701195985

Grimm, N. B., D. Foster, P. Groffman, J. M. Grove, C. S. Hopkinson, K. J. Nadelhoffer, D. E. Pataki, and D. P. C. Peters. 2008. The changing landscape: ecosystem responses to urbanization and pollution across climatic and social gradients. Frontiers in Ecology and the Environment 6:264-272. http://dx.doi. org/10.1890/070147

Groepper, S. R., M. P. Vrtiska, L. A. Powell, and S. E. Hygnstrom. 2012. Evaluation of the effects of September hunting seasons on Canada geese in Nebraska. Wildlife Society Bulletin 36:524-530. http://dx.doi.org/10.1002/wsb.173

Hansson, L., L. Fahrig, and G. Merriam, editors. 1995. Mosaic landscapes and ecological processes (IALE studies in landscape ecology). Chapman and Hall, New York, New York, USA. http:// dx.doi.org/10.1007/978-94-011-0717-4

Harris, E. M., C. Polsky, K. L. Larson, R. Garvoille, D. G. Martin, J. Brumand, and L. Ogden. 2012. Heterogeneity in residential yard care: evidence from Boston, Miami, and Phoenix. Human Ecology 40:735-749. http://dx.doi.org/10.1007/s10745-012-9514-3

Hendrickx, F., J.-P. Maelfait, W. Van Wingerden, O. Schweiger, M. Speelmans, S. Aviron, I Augenstein, R. Billeter, D. Bailey, R. Bukacek, F. Burel, T. Diekötter, J. Dirksen, F. Herzog, J. Liira, M. Roubalova, V. Vandomme, and R. Bugter. 2007. How landscape structure, land-use intensity and habitat diversity affect components of total arthropod diversity in agricultural landscapes. Journal of Applied Ecology 44:340-351. http://dx.doi. org/10.1111/j.1365-2664.2006.01270.x

Hobbs, F., and N. Stoops. 2002. Demographic trends of the 20th century. U.S. Department of Commerce, U.S. Census Bureau. Washington, D.C., USA. [online] URL: http://www.census.gov/ prod/2002pubs/censr-4.pdf

Hope, D., C. Gries, W. Zhu, W. F. Fagan, C. L. Redman, N. B. Grimm, A. L. Nelson, C. Martin, and A. Kinzig. 2003. Socioeconomics drive urban plant diversity. Proceedings of the National Academy of Sciences 100:8788-8792. http://dx.doi. org/10.1073/pnas. 1537557100

Horn, D. J., and S. M. Johansen. 2013. A comparison of birdfeeding practices in the United States and Canada. Wildlife Society Bulletin 37:293-300. http://dx.doi.org/10.1002/wsb.281

Hughes, K. A. 2013. Measuring the impact of viewing wildlife: do positive intentions equate to long-term changes in conservation behaviour? Journal of Sustainable Tourism 21:42-59. http://dx.doi.org/10.1080/09669582.2012.681788

Jassat, W., N. Naicker, S. Naidoo, and A. Mathee. 2013. Rodent control in urban communities in Johannesburg, South Africa: from research to action. International Journal of Environmental Health Research. 23:474-483. http://dx.doi.org/10.1080/0960312$\underline{3.2012 .755156}$

Jensen, R., J. Gatrell, J. Boulton, and B. Harper. 2004. Using remote sensing and geographic information systems to study urban quality of life and urban forest amenities. Ecology and Society 9(5): 5. [online] URL: http://www.ecologyandsociety.org/ vol9/iss5/art5/

Jones, S. G., D. H. Gordon, G. M. Phillips, and B. R. D. Richardson. 2005. Avian community response to a golf-course landscape unit gradient. Wildlife Society Bulletin 33:422-434. http://dx.doi.org/10.2193/0091-7648(2005)33[422:ACRTAG]2.0.CO;2

Kaltenborn, B. P., O. Andersen, J. Vittersø, and T. K. Bjerke. 2012. Attitudes of Norwegian ptarmigan hunters towards hunting goals and harvest regulations: the effects of environmental orientation. Biodiversity and Conservation 21:3369-3384. http:// dx.doi.org/10.1007/s10531-012-0368-1

Kennedy, J. J., and J. W. Thomas. 1995. Managing natural resources as social value. Pages 311-321 in R. L. Knight and S. F. Bates, editors. A new century for natural resource management. Island Press, Washington, D.C., USA.

Kie, J. G., R. T. Bowyer, M. C. Nicholson, B. B. Boroski, and E. R. Loft. 2002. Landscape heterogeneity at differing scales: effects on spatial distribution of mule deer. Ecology 83:530-544. http:// dx.doi.org/10.1890/0012-9658(2002)083[0530:LHADSE]2.0.CO;2

Koval, M. H., and A. G. Mertig. 2004. Attitudes of the Michigan public and wildlife agency personnel toward lethal wildlife management. Wildlife Society Bulletin 32:232-243. http://dx.doi. org/10.2193/0091-7648(2004)32[232:AOTMPA]2.0.CO;2

Krester, H. E., P. D. Curtis, J. D. Francis, R. J. Pendall, and B. A. Knuth. 2009a. Factors affecting perceptions of human-wildlife interactions in residential areas of northern New York and implications for conservation. Human Dimensions of Wildlife 14:102-118. http://dx.doi.org/10.1080/10871200802695594

Krester, H. E., P. D. Curtis, and B. A. Knuth. 2009b. Landscape, social, and spatial influences on perceptions of human-black bear interactions in the Adirondack Park, NY. Human Dimensions of Wildlife 14:393-406. http://dx.doi.org/10.1080/10871200903055318

Krester, H. E., P. J. Sullivan, and B. A. Knuth. 2008. Housing density as an indicator of spatial patterns of reported humanwildlife interactions in northern New York. Landscape and Urban Planning 84:282-292. http://dx.doi.org/10.1016/j.landurbplan.2007.08.007

Kulmatiski, A., and K. H. Beard. 2008. Decoupling plant-growth from land-use legacies in soil microbial. Soil Biology \& Biochemistry 40:1059-1068. http://dx.doi.org/10.1016/j. soilbio.2007.11.020

Langen, T. A., D. T. Bolger, and T. J. Case. 1991. Predation on artificial bird nests in chaparral fragments. Oecologia 86:395-401. http://dx.doi.org/10.1007/BF00317607

Leong, K. M. 2009. The tragedy of being common: landscape change and perceptions of wildlife. Society \& Natural Resources 23:111-127. http://dx.doi.org/10.1080/08941920802438642

Lepczyk, C. A., A. G. Mertig, and J. Liu. 2004a. Assessing landowner activities related to birds across rural-to-urban landscapes. Environmental Management 33:110-125. http://dx. doi.org/10.1007/s00267-003-0036-Z 
Lepczyk, C. A., A. G. Mertig, and J. Liu. 2004b. Landowners and cat predation across rural-to-urban landscapes. Biological Conservation 115:191-201. http://dx.doi.org/10.1016/S0006-3207 (03)00107-1

Lillesand, T. M., and R. W. Kiefer. 2000. Remote sensing and image interpretation. Fourth edition. John Wiley \& Sons, New York, New York, USA.

Liu, J., T. Dietz, S. R. Carpenter, M. Alberti, C. Folke, E. Moran, A. N. Pell, P. Deadman, T. Kratz, J. Lubchenco, E. Ostrom, Z. Ouyang, W. Provencher, C. L. Redman, S. H. Schneider, and W. W. Taylor. 2007. Complexity of coupled human and natural systems. Science 317:1513-1516. http://dx.doi.org/10.1126/ science.1144004

Liu, J., Z. Ouyang, W. W. Taylor, R. Groop, Y. Tan, and H. Zhang. 1999. A framework for evaluating the effects of human factors on wildlife habitat: the case of giant pandas. Conservation Biology 13:1360-1370. http://dx.doi.org/10.1046/j.1523-1739.1999.98418. $\underline{\mathrm{x}}$

Luck, G. W., L. T. Smallbone, and R. O'Brien. 2009. Socioeconomics and vegetation change in urban ecosystems: patterns in space and time. Ecosystems 12:604-620. http://dx.doi. org/10.1007/s10021-009-9244-6

Luck, M., and J. Wu. 2002. A gradient analysis of urban landscape pattern: a case study from the Phoenix metropolitan region, Arizona, USA. Landscape Ecology 17:327-339. http://dx.doi. org/10.1023/A:1020512723753

Lunetta, R. S., R. G. Congalton, L. K. Fenstermaker, J. R. Jensen, K. C. McGwire, and L. R. Tinney. 1991. Remote-sensing and geographic information-system data integration error sources and research issues. Photogrammetric Engineering and Remote Sensing 57:677-687.

Luther, E. 2013. Tales of cruelty and belonging: in search of an ethic for urban human-wildlife relations. Animal Studies Journal 2:35-54.

Manfredo, M. J., J. J. Vaske, P. J. Brown, D. J. Decker, and E. A. Duke. 2009. Wildlife and society: the science of human dimensions. Island Press, Washington, D.C., USA.

Mansfield, C., S. K. Pattanayak, W. McDow, R. McDonald, and P. Halpin. 2005. Shades of green: measuring the value of urban forests in the housing market. Journal of Forest Economics 11:177-199. http://dx.doi.org/10.1016/j.jfe.2005.08.002

Martin, C. A., P. S. Warren, and A. P. Kinzig. 2004. Neighborhood socioeconomic status is a useful predictor of perennial landscape vegetation in residential neighborhoods and embedded small parks of Phoenix, AZ. Landscape and Urban Planning 69:355-368. http://dx.doi.org/10.1016/j.landurbplan.2003.10.034

Martínez-Espiñeira, R. 2006. Public attitudes toward lethal coyote control. Human Dimensions of Wildlife 11:89-100. http:// dx.doi.org/10.1080/10871200600570288

Marzano, M., and N. Dandy. 2012. Recreationist behavior in forests and the disturbance of wildlife. Biodiversity and Conservation 21:2967-2986. http://dx.doi.org/10.1007/s10531-012-0350$\underline{y}$
Mattson, D. J., and E. J. Ruther. 2012. Explaining reported pumarelated behaviors and behavioral intentions among northern Arizona residents. Human Dimensions of Wildlife 17:91-111. http://dx.doi.org/10.1080/10871209.2012.627581

McDonald, A. M. H., R. V. Rea, and G. Hesse. 2012. Perceptions of moose-human conflicts in an urban environment. Alces 48:123-130.

McDonnell, M. J., S. T. A. Pickett, P. Groffman, P. Bohlen, R. V. Pouyat, W. C. Zipperer, R. W. Parmelee, M. M. Carreiro, and K. Medley. 1997. Ecosystem processes along an urban-to-rural gradient. Urban Ecosystems 1:21-36. http://dx.doi.org/10.1023/ A:1014359024275

McKinney, M. L. 2002. Urbanization, biodiversity, and conservation. BioScience 52:883-890. http://dx.doi.org/10.1641/0006-3568 (2002)052[0883:UBAC]2.0.CO;2

McKinney, M. L. 2008. Effects of urbanization on species richness: a review of plants and animals. Urban Ecosystems 11:161-176. http://dx.doi.org/10.1007/s11252-007-0045-4

McMillin, S. C., R. C. Hosea, B. F. Finlayson, B. L. Cypher, and A. Mekebri. 2008. Anticoagulant rodenticide exposure in an urban population of San Joaquin kit fox. Pages 163-163 in R. M. Timm and M. B. Madon, editors. Proceedings of the 23rd Vertebrate Pest Conference, 17-20 March 2008, San Diego, California, USA.

Merkle, J. A., H. S. Robinson, P. R. Krausman, and P. Alaback. 2013. Food availability and foraging near human developments by black bears. Journal of Mammalogy 94:378-385. http://dx.doi. org/10.1644/12-MAMM-A-002.1

Millington, J. D. A., M. B. Walters, M. S. Matonis, and J. Liu. 2010. Effects of local and regional landscape characteristics on wildlife distribution across managed forests. Forest Ecology and Management 259:1102-1110. http://dx.doi.org/10.1016/j. foreco.2009.12.020

Minnis, D. L., and R. B. Peyton 1985. Cultural carrying capacity: modeling a notion. Pages 19-31 in J. B. McAninch, editor. Proceedings of the Symposium of the 55th Midwest Fish and Wildlife Conference, 12-14 December 1993, St. Louis, Missouri, USA.

Morzillo, A. T., and A. G. Mertig. 2011 b. Linking human behavior to environmental effects using a case study of urban rodent control. International Journal of Environmental Studies 68:107-123. http://dx.doi.org/10.1080/00207233.2010.527462

Morzillo, A. T., and A. G. Mertig. 2011a. Urban resident attitudes toward rodents, rodent control products, and environmental effects. Urban Ecosystems 14:243-260. http://dx.doi.org/10.1007/ $\underline{\mathrm{s} 11252-010-0152-5}$

Morzillo, A. T., A. G. Mertig, N. Garner, and J. Liu. 2007. Resident attitudes toward black bears and a proposed recovery in East Texas. Human Dimensions of Wildlife 12:417-428. http:// dx.doi.org/10.1080/10871200701670110

Morzillo, A. T., A. G. Mertig, N. Garner, and J. Liu. 2009. Evaluating hunter support for black bear restoration in East Texas. Human Dimensions of Wildlife 14:407-418. http://dx.doi. org/10.1080/10871200903096189 
Morzillo, A. T., and M. D. Schwartz. 2011. Landscape characteristics affect animal control by urban residents. Ecosphere 2(11):128. http://dx.doi.org/10.1890/ES11-00120.1

Natcher, D., L. Felt, K. Chaulk, and A. Procter. 2012. The harvest and management of migratory bird eggs by Inuit in Nunatsiavut, Labrador. Environmental Management 50:1047-1056. http://dx. doi.org/10.1007/s00267-012-9939-X

Needham, M. D., J. J. Vaske, and M. J. Manfredo. 2004. Hunters' behavior and acceptance of management action related to chronic wasting disease in eight states. Human Dimensions of Wildlife 9:211-231. http://dx.doi.org/10.1080/10871200490479990

Nielsen, C. K., and W. F. Porter. 2011. Ecology and management of deer in developed landscapes: an introduction. Wildlife Society Bulletin 35:124-125. http://dx.doi.org/10.1002/wsb.54

Nowak, D. J. 1993. Historical vegetation change in Oakland and its implications for urban forest Management. Journal of Arboriculture 19:313-319.

O’Donnell, M. A., and A. J. DeNicola. 2006. Den site selection of lactating female raccoons following removal and exclusion from suburban residences. Wildlife Society Bulletin 34:366-370. http://dx.doi.org/10.2193/0091-7648(2006)34[366:DSSOLF]2.0.CO;2

Pincetl, S. 2013. Urban ecology and nature's services infrastructure: policy implications of the million trees initiative of the City of Los Angeles. Pages 61-74 in C. G. Boone, M. Fragkias, editors. Urbanization and sustainability linking urban ecology, environmental justice and global environmental change. Springer-Verlag, New York, New York, USA.

Riley, S. P. D., C. Bromley, R. H. Poppenga, F. A. Uzal, L. Whited, and R. M. Sauvajot. 2007. Anticoagulant exposure and notoedric mange in bobcats and mountain lions in urban southern California. Journal of Wildlife Management 71:1874-1884. http:// dx.doi.org/10.2193/2005-615

Riley, S. J., D. J. Decker, L. H. Carpenter, J. F. Organ, W. F. Siemer, G. F. Mattfeld, and G. Parsons. 2002. The essence of wildlife management. Wildlife Society Bulletin 30:585-593.

Riley, S. P. D., R. M. Sauvajot, T. K. Fuller, E. C. York, D. A. Kamradt, C. Bromley, and R. K. Wayne. 2003. Effects of urbanization and habitat fragmentation on bobcats and coyotes in southern California. Conservation Biology 17:566-576. http:// dx.doi.org/10.1046/j.1523-1739.2003.01458.x

Rodewald, A. D. 2002. Nest predation in forested regions: landscape and edge effects. Journal of Wildlife Management 66:634-640. http://dx.doi.org/10.2307/3803130

Rondeau, D., and J. M. Conrad. 2003. Managing urban deer. American Journal of Agricultural Economics 85:266-281. http:// dx.doi.org/10.1111/1467-8276.00118

Rosenfield, G. H., and K. Fitzpatricklins. 1986. A coefficient of agreement as a measure of thematic classification accuracy. Photogrammetric Engineering and Remote Sensing 52:223-227.

Savard, J.-P. L., P. Clergeau, and G. Mennechez. 2000. Biodiversity concepts and urban ecosystems. Landscape and Urban Planning 48:131-142. http://dx.doi.org/10.1016/S0169-2046 (00)00037-2
Sheets, V. L., and C. D. Manzer. 1991. Affect, cognition, and urban vegetation: some effects of adding trees along city streets. Environment and Behavior 23:285-304. http://dx.doi. org/10.1177/0013916591233002

Steenwerth, K. L., L. E. Jackson, F. J. Calderón, M. R. Stromberg, and K. M. Scow. 2002. Soil microbial community composition and land use history in cultivated and grassland ecosystems of coastal California. Soil Biology and Biochemistry 1599-1611. http://dx.doi.org/10.1016/S0038-0717(02)00144-X

Steinberg, R. M., A. T. Morzillo, S. P. D. Riley, and S. G. Clark. In press. People, predators and place: rodenticide impacts in a wildland-urban interface. Rural Society.

Theobald, D. M. 2004. Placing exurban land-use change in a human modification framework. Frontiers in Ecology and the Environment 2:139-144. http://dx.doi.org/10.1890/1540-9295 (2004)002[0139:PELCIA]2.0.CO:2

Turner, M. G., R. H. Garner, and R. V. O’Neill. 2001. Landscape ecology in theory and practice. Springer-Verlag, New York, New York, USA.

Ulrich, R. S. 1986. Human responses to vegetation and landscapes. Landscape and Urban Planning 13:29-44. http://dx. doi.org/10.1016/0169-2046(86)90005-8

Urbanek, R. E., C. K. Nielsen, M. A. Davenport, and B. D. Woodson. 2013. Determinants of public perceptions of suburban deer density. Human Dimensions of Wildlife 18:82-96. http://dx. doi.org/10.1080/10871209.2012.719174

U.S. Environmental Protection Agency (US EPA). 2008. Risk mitigation decision for ten rodenticides. U.S. Environmental Protection Agency, Washington, D.C., USA. [online] URL: http://www.epa.gov/oalj/filings/Reckitt HrgReq Ex03.pdf

VerCauteren, K. C., M. J. Lavelle, and S. Hygnstrom. 2006. From the field: fences and deer-damage management; a review of designs and efficacy. Wildlife Society Bulletin 34:191-200. http:// dx.doi.org/10.2193/0091-7648(2006)34[191:FADMAR]2.0.CO;2

Warnken, J., D. Thompson, and D. H. Zakus. 2001. Golf course development in a major tourist destination: implications for planning and management. Environmental Management 27:681-696. http://dx.doi.org/10.1007/s002670010179

White, C. L., and M. B. Main. 2005. Waterbird use of created wetlands in golf-course landscapes. Wildlife Society Bulletin 33:411-421. http://dx.doi.org/10.2193/0091-7648(2005)33[411:WUOCWI] 2.0.CO;2

Whittaker, D., M. J. Manfredo, P. J. Fix, R. Sinnott, S. Miller, and J. J. Vaske. 2001. Understanding beliefs and attitudes about an urban wildlife hunt near Anchorage, Alaska. Wildlife Society Bulletin 29:1114-1124.

Wittmann, K., J. J. Vaske, M. J. Manfredo, and H. C. Zinn. 1998. Standards for lethal response to problem urban wildlife. Human Dimensions of Wildlife 3:29-48. http://dx.doi.org/10.1080/10871$\underline{209809359137}$

Zinn, H. C., and C. L. Pierce. 2002. Values, gender, and concern about potentially dangerous wildlife. Environment and Behavior 34:239-256. http://dx.doi.org/10.1177/0013916502034002005 